\title{
THE
}

\section{Valuation of the External Costs of Unconventional Oil and Gas Development: The Critical Importance of Mineral Rights Ownership}

Andrew Boslett

University of Rhode Island

Todd Guilfoos

University of Rhode Island, guilfoos@uri.edu

Corey Lang

University of Rhode Island, clang@uri.edu

Follow this and additional works at: https://digitalcommons.uri.edu/enre_facpubs

The University of Rhode Island Faculty have made this article openly available.

Please let us know how Open Access to this research benefits you.

This is a pre-publication author manuscript of the final, published article.

Terms of Use

This article is made available under the terms and conditions applicable towards Open Access Policy Articles, as set forth in our Terms of Use.

\section{Citation/Publisher Attribution}

Boslett, A., Guilfoos, T., \& Lang, C. (2019). Valuation of the External Costs of Unconventional Oil and Gas Development: The Critical Importance of Mineral Rights Ownership. Journal of the Association of Environmental and Resource Economists,6(3), 531-561. doi: 10.1086/702540

Available at: http://dx.doi.org/10.1086/702540

This Article is brought to you for free and open access by the Environmental and Natural Resource Economics at DigitalCommons@URI. It has been accepted for inclusion in Environmental and Natural Resource Economics Faculty Publications by an authorized administrator of DigitalCommons@URI. For more information, please contact digitalcommons-group@uri.edu. 


\title{
Valuation of the External Costs of Unconventional Oil and Gas Development: The Critical Importance of Mineral Rights Ownership
}

\author{
Andrew Boslett*, Todd Guilfoos ${ }^{\alpha}$, and Corey Lang ${ }^{\beta}$ \\ University of Rhode Island
}

March 16, 2018

\begin{abstract}
We quantify the externalities associated with unconventional oil and gas development using hedonic valuation. One complication in determining local impacts is that some but not all properties are unified with mineral rights, which enable the residents to financially benefit from drilling, and this information is typically unobserved by researchers. To overcome this issue, we exploit the mineral severance legacy of the homestead act extensions of the $20^{\text {th }}$ century to identify properties in Western Colorado that do not have mineral rights and are therefore only impacted negatively by drilling. We find housing prices decline about $35 \%$ when drilling occurs within one mile. Treated properties are affected by highly-intensive drilling ( 16 wells drilled within a mile, on average) and there is suggestive evidence of non-linear impacts on a per-well basis. Our estimate of local costs is larger than those found elsewhere in the literature, which demonstrates the critical importance of mineral ownership.
\end{abstract}

Keywords: unconventional oil and gas development; hydraulic fracturing; horizontal drilling; federal mineral ownership; mineral severance; hedonic valuation

JEL codes: Q3, Q5

\footnotetext{
* 265 Crittenden Blvd., Rochester, NY 14620. Email: andrew_boslett@ urmc.rochester.edu (Corresponding Author). $\alpha 1$ Greenhouse Rd., Kingston, RI 02881. Email: quilfoos@uri.edu. $\beta 1$ Greenhouse Rd., Kingston, RI 02881. Email: clang@uri.edu. We thank Stephen Atlas, Lonny Bagley, Michael Delgado, Timothy Fitzgerald, Carrie Gill, Claudia Hitaj, Heather Stephens, Matthew Sura, Jeremy Weber, seminar participants at the University of Rhode Island, the USDA's Economic Research Service, AAEA Annual Conference, NAREA, and participants at the United States Association for Energy Economists for useful comments and suggestions. We also thank three anonymous reviewers whose suggestions improved the paper. We are grateful to Garfield, Mesa, and Rio Blanco assessment and GIS departments; Kirby Wynn of the Garfield County Energy Advisory Board; Steven Hall, Martin Hensley, Deanna Masterson and Courtney Whiteman of the Bureau of Land Management's Colorado Office; Lois Dunn, a real estate broker from Mesa County; and a number of local real estate agents that preferred to remain anonymous. They have helped us obtain data and better understand local and state institutional issues related to both unconventional oil and gas development and mineral ownership. We would also like to thank Drillinginfo for providing access to their proprietary well database. Any errors are our own.
} 


\section{Introduction}

Shale and tight oil and gas basins have emerged as important sources of energy in the United States through innovations in hydraulic fracturing and horizontal drilling. This development has led to significant impacts on residents and landowners that are close to drilling activities. There are environmental risks associated with unconventional oil and gas development related to groundwater contamination (Osborn et al. 2011), surface water pollution (Olmstead et al. 2013), wastewater management (Rahm and Riha 2012), and infant health (Hill 2013; McKenzie et al. 2014). However, there are positive impacts, especially for those residents that lease their mineral rights to drilling companies in return for signing bonuses and royalty payments (Fitzgerald 2014; Hardy and Kelsey 2015). ${ }^{1}$ Royalty payments can be as high as $20 \%$ of the value of production and lease signing bonuses can reach into the thousands of dollars per acre leased (e.g., Brasier et al. 2011; Kelly-Detwiler 2013).

There is a growing body of literature in economics that estimates the value of local impacts of unconventional oil and gas development through hedonic valuation, with remarkable variation in estimates. Gopalakrishnan and Klaiber (2014) examine price responses in southwestern Pennsylvania and find that prices can decline by as much as $22 \%$ for private wellwater dependent properties, but generally are smaller and short lived. Muehlenbachs, Spiller, and Timmins (2015) use data from across Pennsylvania and find that shale development can lead to depreciation as high as $17 \%$ for well water properties within 1.5 kilometers of an unconventional drill site. They also find that drilling can have a small positive impact on property sale prices in public water supply areas. Delgado, Guilfoos, and Boslett (2016) use data from Northeastern Pennsylvania and find no robust impact of nearby drilling. Boslett, Guilfoos, and Lang (2016) examine the impact of the New York State moratorium on unconventional drilling and find New York properties most likely to be impacted by shale gas development declined $24 \%$ in value relative to comparable Pennsylvania properties after the moratorium. They interpret this finding as a positive expected net value of shale gas development. Weber and Hitaj (2015) find evidence

\footnotetext{
${ }^{1}$ The United States is unique in that private citizens can own the minerals underneath their property. In most countries, it is the government or the crown that owns all subsurface rights (Kulander 2013). Since U.S. citizens can own their properties' minerals, they can financially benefit from drilling through leasing. The possibility of financial benefits has led to more public support for unconventional oil and gas development in the United States than in other countries (e.g., Stevens 2010; Gény 2010). Private mineral rights ownership has been crucial in driving development in the United States (Wang and Krupnick 2013).
} 
of appreciation in farm property values in both Pennsylvania and Texas, especially during leasing periods. Importantly, their estimates are attenuated in areas with significant mineral severance. Using zip code level aggregate data from Texas, Weber, Burnett, and Xiarchos (2016) find evidence of both appreciation and depreciation due to shale development. In Colorado, Bennett and Loomis (2015) find mixed results that are often not statistically significant. Also in Colorado, James and James (2015) find that a one kilometer decrease in distance away from an unconventional well is associated with a 7 to $20 \%$ decrease in sale price. However, this effect can be mitigated if the property is above a horizontal well lateral, which suggests royalty payments from leasing are capitalized into prices. There remain large variations in estimates of shale gas development on property prices without sufficient explanation.

One potential reason for the contrasting results is that mineral right ownership is not explicitly accounted for in these studies. ${ }^{2}$ Mineral ownership is important because it firmly demarcates those who financially benefit from unconventional gas development through royalties and lease payments versus those who do not. Without information about mineral ownership at the property level, it is unclear how to separate the negative impacts (aesthetic, environmental, and health costs) and positive financial impacts (royalty and lease payments) of proximity to shale development in most study areas.

In Pennsylvania, which is the focus of several of the above studies, mineral right ownership varies substantially and systematically across the state. Mineral rights are more often severed from surface rights in western Pennsylvania, which has a long legacy of energy extraction, versus northeastern Pennsylvania, where energy extraction only started recently (Kelsey, Metcalf, and Salcedo 2012). If mineral severance is less common in northeastern Pennsylvania, then it is not surprising that the valuation studies focused on the area estimate less negative (or even positive) impacts of shale gas. ${ }^{3}$ It is noteworthy that Muehlenbachs et al. (2015) estimate the risks to groundwater by comparing the sources of water and proximity to shale gas development. This would only lead to bias if mineral rights differed systematically by water source in a narrow band around the piped water boundary, which their research design minimizes.

\footnotetext{
${ }^{2}$ See Table $1 \mathrm{~A}$ in the online appendix on a review of the previous literature and how each paper contextualized the issue of mineral rights ownership.

${ }^{3}$ Consistent with this interpretation of the valuation results, homeowners that do not own mineral rights have an increased perception of environmental risk (Brasier et al. 2013) and frustration (Collins and Nkansah 2015).
} 
While the important distinction between private well water and public water properties has been identified by the existing hedonic valuation literature, the critical issue of mineral rights ownership has not been resolved. This has not been a lack of foresight or understanding by researchers of the importance of mineral ownership in how people are impacted by drilling. Rather, this information is extremely difficult for researchers to obtain. ${ }^{4}$

In this paper, we resolve the issue of unknown mineral rights by exploiting historical severance in mineral rights ownership. During the $19^{\text {th }}$ century, the United States expanded its boundaries through territorial acquisition. Over time, the country developed this land by granting both land and mineral rights to settlers starting with the Homestead Act of 1862. In the late 1800 s and early 1900s, the federal government recognized both the increasing value of energy for economic growth and the government's inability to properly identify "mineral" lands, which they kept in federal ownership, and "nonmineral" lands, which they disbursed for homesteading. In response, the federal government passed a series of laws that increasingly reserved minerals in federal ownership, leading to the Stock-Raising Homestead Act of 1916 (SRHA). The SRHA continued the tradition of public land disbursement, but the federal government retained ownership of minerals in all land disbursed after 1916 (Gates 1977; Harrison 1989). ${ }^{5}$

To build our dataset of transactions, we identify residential properties in Colorado located on land originally distributed under the SRHA and other policies that retained mineral ownership in the federal government. Thus, the federal government owns the mineral rights for each of these properties and current residents do not benefit financially from lease and royalty payments. Our study area is on the western slope of Colorado, centered in Garfield, Mesa, and Rio Blanco counties. Western Colorado was one of the major areas of post- 1916 homesteading and this region is one of the primary locations of unconventional oil and gas development in the state.

Our hedonic analysis suggests that houses within one mile of an unconventional drill site

\footnotetext{
${ }^{4}$ Mineral right ownership information is held in county deeds offices and is not commonly included in property deeds. The chain of title can be unclear, especially when the mineral estate was separated from the surface estate after the property was originally conveyed. Charting mineral rights ownership over time is the full-time job of a title abstractor (Wilson 2014). Suffice it to say, it would be difficult for researchers to successfully obtain mineral rights ownership information for a large property transaction database. One of the authors of this study spent a day at Pennsylvania's Bradford County's Register and Recorder office researching mineral rights transfers and can attest to this.

${ }^{5}$ Although there were other federal policies passed in the early $20^{\text {th }}$ century with a similar effect (e.g., Agricultural Entry Act of 1914), we focus most of our discussion on the Stock-Raising Homestead Act of 1916, as it completely discontinued the conveyance of minerals through homestead patents. It is also the largest source of privately held land with federal minerals (Watson, 2008).
} 
sell for $34.8 \%$ less than comparable properties without proximate drilling. This identification is based on 783 properties with a split estate status of which 98 are treated with proximity to drilling. This result is robust across various subsets of the data and alternative regression specifications, including a repeat sales model, a matching model, and a difference-in-differences model. When multiplied by the average house price of $\$ 183,300$, this discount translates to a price reduction of $\$ 63,788$, which equals $\$ 3,952$ when annualized by a 30-year mortgage and a $5 \%$ interest rate. We interpret this price difference as the household valuation of the external environmental and health costs associated with proximity to unconventional oil and gas development.

Our findings corroborate the negative valuations found in other papers, but are $60 \%$ larger in magnitude than the largest existing negative estimate on aggregate. ${ }^{6}$ Estimates from other studies are based on a variety of measures (e.g., per-well, per-well pad, distance to closest well, presence of well). While it is difficult to compare across measures, our back-of-theenvelope calculations indicate our aggregate estimate of presence is greater than aggregate estimates from other hedonic studies. ${ }^{7}$ The disparity between our estimates and other's studies demonstrates the importance of understanding mineral rights, as financial benefits of drilling are capitalized into housing prices and can adulterate estimates of external costs. Supporting this conclusion, we estimate hedonic models using Western Colorado properties with unknown mineral rights ownership, mirroring the setup of prior studies, and find much smaller and statistically weaker impacts of proximity (available in the online appendix).

Our paper is structured as follows. We start in Section 2 with a conceptual framework that discusses the issue of mineral rights ownership in valuation of unconventional oil and gas development. In Section 3, we outline the history of public land disposal and how it came to be that the later policies in the early $20^{\text {th }}$ century reserved mineral ownership to the federal government. In Section 4, we discuss our data set and how we obtained it. We then follow in Section 5 with a discussion our methodological approach and the assumptions we use in our interpretation of our model results. In Section 6, we present our results, and Section 7 concludes.

\section{Conceptual Framework}

\footnotetext{
${ }^{6}$ Krupnik and Escharte (2017) provide a comprehensive review of this literature and discuss magnitudes of findings.

${ }^{7}$ In Section 6, we also present results from models that allow for an average effect of presence and a per-well intensity effect. The per-well estimated coefficient is smaller than some others in the literature, but the presence effect remains large and indicates strong non-linearities.
} 
In this section, we outline the potential biases in hedonic valuation of unconventional oil and gas development. The net effect of oil and gas development vary across mineral estate classifications. While environmental and health risks should be independent of mineral rights, the vast majority of financial benefits, such as a lease signing bonus and production-based royalties, only accrue to households with mineral rights. Thus, in a split estate, where the surface property owner does not own the mineral rights, the surface owner cannot financially benefit from drilling. Only residential properties that are unified with mineral rights can receive direct financial benefits. One way that surface ownership can be split from mineral rights is through the issuance of a severance deed, in which a private landowner sells the land but retains the minerals. This situation is common in areas of the country that have experienced historical energy development and mining (e.g., Kelsey et al. 2012; Pender, Weber, and Brown 2014; Railroad Commission of Texas 2015). It was also done as a result of the homestead act extensions of the early $20^{\text {th }}$ century, such as the Stock-Raising Homestead Act of 1916, which we detail in the following section. A split estate is analogous to mineral ownership law in other countries: private land owners neither control the course of oil and gas development, nor financially benefit from it. The mineral estate is essentially dominant, which means that the surface owner must accommodate exploration and production by the mineral owner.

We define the price of property $i$ as $P_{i}(\cdot)$, a function of environmental characteristics $E_{i}$, the financial benefits of oil and gas development $F_{i}$, and structural characteristics. The environmental quality of the property is influenced by proximate oil and gas development, $D_{i}$. These impacts could be associated with diminished water quality, air quality, forest and habitat fragmentation, or visual or noise disamenities. We assume that the impact of $D_{i}$ on $E_{i}$ is uniform for all properties. Additionally, the financial benefits of owning the property are impacted by $D_{i}$. This model presents the difference between treatment and control, where treatment is defined as properties in proximity to oil and gas development. This presumes that area-wide effects of drilling activity are not a consequence of proximate drilling activity, but rather overall drilling activity in the area, and affect our control and treatment properties equally. Examples of areawide effects might include adjustments in the job market or a boost to local government finances through additional taxes, both of which may affect the area demand for housing.

In this framework, mineral ownership is defined as a binary variable, $M_{i}$, equal to 1 if the 
property's surface estate is connected with its mineral estate and equal to 0 otherwise. The net valuation of unconventional oil and gas development for property $i$ can be decomposed as follows:

$$
\text { (1) } \text { Valuation }_{i}=\frac{\partial P_{i}}{\partial E_{i}} \cdot \frac{\partial E_{i}}{\partial D_{i}}+M_{i} \cdot \frac{\partial P_{i}}{\partial F_{i}} \cdot \frac{\partial F_{i}}{\partial D_{i}}
$$

Thus, the valuation of development, as capitalized by housing prices, is a net valuation of the environmental impacts of development (first term) and the financial benefits of development, contingent on ownership of the property's mineral estate (second term). For the sake of simplicity, we re-write the equation as:

$$
\text { (2) } \text { Valuation }_{i}=C+M_{i} \cdot B
$$

where $C$ and $B$ refer to the true values of the capitalization of the financial benefits and environmental costs (Table 1). If a property has mineral rights, then the estimated valuation will be the net impact, $\mathrm{C}+\mathrm{B}$. However, if a property is a split estate, then the estimated valuation will be the external costs of being proximate to drilling.

In order for researchers to estimate valuation with real data, a residential property market level analysis is required. We define $\theta$ as the proportion of properties unified with their minerals. Using the terminology from Table 1, we have:

$$
\text { (3) Estimated Valuation }=(C+B) \cdot \theta+C \cdot(1-\theta)
$$

The estimated valuation is conditional on the proportion of treated properties with mineral rights, which is unknown to the researcher. Knowing either $\mathrm{C}+\mathrm{B}$ or $\mathrm{C}$ is useful for understanding local impacts and for guiding policy. But a weighted average of the two with an unknown weight yields imprecise guidance.

In this paper, we take advantage of the historical split in mineral rights from surface rights caused by the SRHA and other public land disposal policies of the early $20^{\text {th }}$ century. Thus, in our sample, $\theta=0$ and we can isolate the environmental costs, $C$, from the financial benefits of development. This framework assumes there are no area level impacts of oil and gas development on properties which differ by mineral rights ownership, which would impact the estimate of proximity to wells. This potential issue is easily addressed with information about mineral rights ownership over the entire population of sales, or restricting the sample to only those properties without mineral rights ownership, i.e. $\theta=0$, as we do in this study.

There are significant challenges in identification when evaluating properties with 
unknown mineral ownership and comparing them with properties with federal mineral ownership. There are possible unobservable differences related to the land's original disposal. There may also be differences in royalty and lease payment negotiations and surface use agreements between wells drilled on or near lands with federal mineral ownership versus those without federal mineral ownership. Wells on privately-owned properties with non-federal mineral ownership are subject to state regulations; those on lands with federal mineral ownership are subject to both state and federal regulations. Private landowners may also be more (or less) likely to implement significant surface use protections than the federal government. The siting of wells on privately-owned land with mineral rights may be endogenous causing identification problems. We also do not know the relative proportion of properties with connected mineral ownership. Any estimated effect for these properties is an average effect of living near a well between properties with or without connected minerals and is thus an unknown weighted average of the financial benefits versus environmental costs. With these potential issues in mind, in our primary specification, we use a subset of properties designed to cleanly identify split mineral rights ownership.

\section{History of the Homestead Acts}

During the first half of the $19^{\text {th }}$ century, the United States made a series of land acquisitions that greatly increased the land area of the country (e.g., the Louisiana Purchase). How to apportion and settle these lands were major political questions facing the United States (Gates 1968; Anderson and Hill 1990). Initially, the federal government's policy revolved around auctions and land sales, which allowed the federal government to generate income while encouraging settlement of the western public domain (Gates 1968). To help defray the cost of building railroad track networks across the country, the federal government also gave significant amounts of land to railroad companies (Roberts 2011). From 1830 to 1888 , more than 300 million acres of land were given to railroad companies

(Harrison 1989). This land was typically of high quality and close to the towns and cities that would ultimately make up the hubs of the transcontinental railroads. The railroad companies sold this land to individuals and families moving into the west for prices much higher than those faced by squatters through preemption (Gates 1968). 
However, these and other policies encouraged speculation and massive landholdings by a small number of companies. With these issues in mind, federal policy transitioned in the latter half of the $19^{\text {th }}$ century and early $20^{\text {th }}$ century to one based on free disposal of land (Allen 1991). The movement culminated in a series of homestead acts in the late 1800s and early 1900s. These acts provided free land to settlers on the condition that some ranching, cropping or timber management would be performed on the property. In total, homesteaders received patents to 253 million acres of the continental United States. The relative portion of total land disbursed to homesteaders was particularly high in the Great Plains and Rocky Mountain states. In Colorado, 33\% of the state's land was distributed to homesteaders (Edwards 2009).

Early homestead acts apportioned both surface and subsurface rights to homesteaders. This was the case for the original Homestead Act of 1862, signed by President Abraham Lincoln after the separation of the Confederacy from the United States. These lands were selected for disbursement due to their perceived "nonmineral" character, as delineated by General Land Office's entrymen and surveyors. All lands with mineral potential were retained by the federal government. However, nonmineral vs. mineral land demarcation was imperfect due to technology limitations and pervasive fraud (Harrison 1989).

Recognizing the limitations of the original policy (Doran and Cifor 2012) and the need for mineral conservation for future generations (Gates 1968), the federal government passed a series of acts that explicitly outlined their desire to retain mineral ownership while promoting continued settlement. These acts included the Coal Lands Acts of 1909 and 1910, the Agricultural Entry Act of 1914, and the Stock-Raising Homestead Act of 1916 (SRHA). The Coal Lands Acts of 1909 and 1910 allowed homestead patents on lands suspected to hold coal reserves but reserved federal ownership of the resource (Fleck, 1974). The Agricultural Entry Act of 1914 reserved federal ownership of a suite of minerals, including oil and gas, in future homestead entries made under earlier land acts (Verity and Young, 1971).

The Stock-Raising Homestead Act of 1916 expanded the Agricultural Entry Act to include all minerals. The legacy of this policy is considerable. More entries were filed under the SRHA than in any of the other land acts of the 1900s (Laitos, Zellmer, and Wood 
2015) and it is the largest source of privately-held land with federal minerals (Watson, 2008). The SRHA effectively discontinued the mineral-nonmineral classification system (Harrison 1989). Homesteading individuals were granted no more than a section of land for ranching and forage crop production, conditional on making permanent improvements on the land within three years of the entry date. However, the federal government would retain mineral ownership of all lands disbursed through the SRHA:

"That all entries made and patents issued under the provisions of this Act shall be subject to and contain a reservation to the United States of all coal and other minerals in the lands so entered and patented, together with the right to prospect for, mine, and remove the same." ${ }^{8}$

Homesteaders and other later surface right owners must allow access to the land for subsurface exploration and production:

"Any person who has acquired from the United States the coal or other mineral deposits in any such land, or the right to mine and remove the same, may reenter and occupy so much of the surface thereof as may be required for all purposes reasonably incident to the mining or removal of the coal or other minerals, first, upon securing the written consent or waiver the homestead entryman or patentee; second, upon payment of the damages to crops or other tangible improvements to the owner thereof...or, third, in lieu of either of the forgoing provisions, upon the execution of a good and sufficient bond...to secure the payment of such damages to the crops or tangible improvements of the entryman or owner."

This condition precludes the surface owner from preventing mineral exploration. This is because the intent of the act was to continue the practice of homesteading and agricultural development of the West without compromising the federal government's

\footnotetext{
${ }^{8}$ The Statues at Large of the United States of America from December, 1915 to March, 1917. Session 2. Chapter 9. Section 9. Page 864.

${ }^{9}$ The Statues at Large of the United States of America from December, 1915 to March, 1917. Session 2. Chapter 9. Section 9. Page 864.
} 
interest in mineral exploration (Tanke and Putz 1982). If the surface owner had the right to prevent production from the property, the mineral estate would have no value.

The SRHA led to a significant amount of private land with federal mineral ownership in the western United States. Out of approximately 300 million acres conveyed to private individuals through the various homesteading acts (Loomis 2002), nearly 60 million acres have been split from their underlying subsurface estates as a result of the SRHA. In Colorado alone, these lands total 5.2 million acres. Figure 1 shows lands with federal mineral ownership across Colorado.

On privately-owned lands with federal mineral ownership as a result of the SRHA or AEA, the mineral lessee must make a "good faith effort" to secure surface owner consent to access the property (Bureau of Land Management 2007). However, the surface estate owner is only entitled to compensation associated with damages to crops and agricultural-related improvements. Thus, in the context of shale gas extraction, a homeowner may be exposed to water contamination, air pollution, noise, and visual disamenities, but not be entitled to compensation. ${ }^{10}$

More recent legislation has maintained surface use access for mineral rights interests while providing some limited protection to surface owners through accommodation doctrine. In Colorado, the principle requires that operators make a serious effort towards accommodating the landowner's use of the land by locating infrastructure and adjusting operation plans to reduce impacts of oil and gas development on the land. ${ }^{11}$ The mineral owner may only access the surface if there are no other alternatives that could avoid interference with the present surface uses (Johnson 1998). However, it is difficult for surface owners to prove that the use of the surface by the mineral owner is not "reasonable." Thus, mineral rights dominance has been kept in place even with accommodation doctrine codified by legislation (Kulander 2013).

\section{Empirical Setting and Data}

\footnotetext{
${ }^{10}$ If the mineral lessee cannot come to a surface use agreement with the land owner, the company must rely on a performance bond to indemnify against unforeseen damages to crops and agricultural improvements. However, this bond does not cover all damages that a surface owner may face from drilling. It is typically valued at $\$ 2,000$. Thus, it is common for property owners to receive less money than they would expect given the use of their land (Fitzgerald, 2010).

${ }^{11}$ Colorado Revised Statute 34-60-127.
} 
Colorado has a long history of oil and gas development. According to data from the U.S. Geological Survey (Biewick 2008), most Colorado counties have experienced oil and gas exploration since the early 1900s. Some counties, especially those outside of the intermountain areas, have seen a large increase in oil and gas development since the 1940s.

More recently, the new technologies of horizontal drilling and hydraulic fracturing have been used for extraction in Colorado. According to Drillinginfo, over 11,000 horizontal wells were drilled in Colorado between 2000 and 2014. Figure 1 displays the spatial distribution of this drilling. There are generally three drilling hotspots: northwestern Colorado, Weld County on Colorado's Front Range, and La Plata and Montezuma counties in southwestern Colorado. Our study focuses on northwestern Colorado because there is extensive federal mineral ownership in this area. Bennett and Loomis and (2015) and James and James (2016) examine impacts in Weld County, which is more densely populated, but has much less federal mineral ownership than northwestern Colorado. Montezuma County contains many tribal lands, which complicates analysis due to jurisdictional complexity of mineral development and policy (West 1992).

In this study, we use residential property transaction data from Garfield, Mesa, and Rio Blanco counties in western Colorado. ${ }^{12}$ We received the data from each county assessor's office. All transactions in our analyses occurred from 2000 to the end of 2014. All transaction data contain property characteristic information including the number of bedrooms and bathrooms, living area, age of the property's structure, and its classified property or land use. We include only those transactions that are defined as residential or agricultural with a residential building $(\mathrm{N}=55,114)$. All mobile homes are dropped from the analyses $(\mathrm{N}=2,819) .{ }^{13}$ The data allow us to observe multiple sales per property, not just the most recent. All transactions that had more than seven bedrooms were dropped out of concern that the properties were apartment buildings $(\mathrm{N}=16)$.

In order to focus on properties without mineral rights, we use the federal mineral ownership data from the Bureau of Land Management's Colorado GIS office. ${ }^{14}$ We overlay

\footnotetext{
${ }^{12}$ We assume that the properties from these three counties in western Colorado make up a single housing market. This is a common assumption in hedonic analyses, especially in studies that rely on regional or multi-county data (e.g., Muehlenbachs et al. 2015).

13 Results from our main models are robust to including mobile homes and are available in the online appendix (Table 5A).

14 "Statewide Federal Mineral Ownership" data product.
} 
federal oil and gas ownership data layers with parcel boundaries. We include properties in our final sample that are completely contained within the federal mineral ownership boundaries $(\mathrm{N}=$ 871). ${ }^{15}$ Figure 2 illustrates the process of identifying residential properties with federal mineral ownership. The points represent the centroids of parcels sold in a sub-region of our study area. White points represent sales of properties that are outside of the area of federal mineral ownership. Grey points represent sales of properties with boundaries that overlay, but are not within, the federal mineral ownership areas. It is possible that some of these properties are split from their minerals, especially those with significant coverage within the federal mineral ownership areas. However, the mineral estate designation is unclear. Black dots represent sold properties with boundaries that are completely within the extent of federal mineral ownership, and thus were split from their minerals by the homestead act extensions of the $20^{\text {th }}$ century.

While this cuts $98 \%$ of the transactions in our database, this restriction is necessary to identify the subset of properties that do not benefit financially from nearby drilling. It is likely that some properties outside of the federal mineral ownership boundary do not own mineral rights, but it is unknown on a property-by-property basis. Thus, the federal mineral ownership sample provides the best estimate of the external costs of local oil and gas development. Lastly, we cut all observations below the $5^{\text {th }}$ and above the $95^{\text {th }}$ percentile of the sale price distribution to remove the influence of outliers. Our final sample is 783 transactions.

We received directional and horizontal well site data from Drillinginfo. In our three counties, there were 4,374 horizontal wells drilled from 2000 to 2014 . These wells targeted various tight sandstone formations in the Piceance Basin, which crosses our study area. Most wells were drilled into the Williams Fork tight sandstone formation (Holmes et al. 2015). Other tight sandstones with producing horizontal wells include the Corcoran, Cozzette, and Rollins formations (Johnson and Roberts 2003). The Mancos Shale play, which was recently classified as holding some of the largest unconventional oil and gas reserves in the country (Hawkins et al. 2016), has also been targeted during our study's time period. ${ }^{16}$

\footnotetext{
${ }^{15}$ There were data scale and alignment issues between our parcel data and our mineral ownership data. As a result, our restriction is conservative. There are likely other properties that are severed from their oil and gas rights by the SRHA but are not fully within the federal mineral ownership extent. We test our results using less restrictive definitions of a split estate (i.e., 75 and $90 \%$ of property within federal mineral ownership boundary) and find robust results (also available in Table 5A).

${ }^{16}$ As a note, the Colorado Oil and Gas Conservation Commission has GIS data available on the direction and length of horizontal lateral paths. This data could have been used to identify properties that are close, but do not overlie, well laterals. These properties would not receive royalty payments but they would be impacted by the costs of
} 
In ArcGIS, we calculate the distance to the closest well site at the time of sale. In addition, we calculated additional spatial statistics associated with distance to the closest municipality (U.S. Census definition) and the percentage of the property in an agricultural use from the National Land Cover Dataset 2001 to use as control variables in our regression model. Table 2 provides summary statistics for our preferred sample of split estate properties. $12.5 \%$ of our sample properties are within one mile of a horizontal well. As we'll show in the next section, this classification defines treatment. Thus, our sample relies on only 98 treated observations for identification. While this is justified given the natural experiment, care must be used when applying our findings to other areas of shale gas development. Further, most of our treated properties in our main specification come from one subdivision in the small combined towns of Battlement Mesa, $\mathrm{CO}$ and Parachute, CO. This distribution of properties increases the risk that our estimates are subject to individual time varying shocks that are correlated with shale gas development near this particular subdivision. While the criteria for creating our main sample are ideal for identifying negative externalities, the concentration of treated properties in a single subdivision creates the possibility that our estimate is biased by place-specific shocks. In order to bolster our findings, we supplement our main analysis with a quasi difference-in-difference model that restricts analysis to subdivisions in this combined town. In this model, we control for federal mineral rights status to establish the effect of treatment while controlling for common trends in property prices. The average treated property has 16.8 wells within one mile, demonstrating the high degree of activity in this area. The average selling price is $\$ 183,300$, and the average lot size is 6.4 acres. No properties in our preferred sample have an on-property horizontal well. This is important because surface use agreements must be in place at the time of operation, so these payments are unlikely to adulterate the effects estimated using this sample. ${ }^{17}$

As discussed in the introduction, prior hedonic valuation papers have focused on differences in impacts between municipal water and private well water properties

\footnotetext{
nearby development. However, the quality of this data is uncertain. Pre-2012 well lateral paths were "automatically generated" and "do not represent the true wellbore path." Only wells drilled after 2012 are likely to depict the actual path (See http://cogcc.state.co.us/data2.html\#/downloads).

${ }^{17}$ None of our treated properties were located within a BLM oil and gas unit. While any surface use payments would attenuate our estimates, there is not sufficient data to understand how often split estate owners in our study area receive them. One primary vehicle for surface use payments - protection bonds - are proprietary documents. However, a land law examiner with the Bureau of Land Management's Colorado Office said that these are relatively rare. To her knowledge, only two have been passed Colorado from 2013 to the present.
} 
(Gopalakrishnan and Klaiber 2014, Muehlenbachs et al. 2015, Boslett et al. 2016). In Colorado, data do not exist as to which properties have private vs. public water supply. Our split estate properties exist outside of municipal boundaries, which is a proxy for public water service. However, it is possible that some of our properties have access to public water systems, as they seem to be clustered in certain pockets of the counties. ${ }^{18}$ Therefore, our estimates may not be applicable to households that face the risk of groundwater contamination.

\section{Methodology}

We use the hedonic price method to estimate the effect of drilling proximity on housing prices (Rosen 1974). Our basic specification is:

$$
\text { (4) } \ln \left(p_{i s t}\right)=\beta \cdot I\left(\text { wells }_{\text {ist }}>0\right)+X_{\text {ist }}^{\prime} \cdot \delta+\gamma_{s}+\tau_{t}+\varepsilon_{i s t} .
$$

$p_{i s t}$ is the sale price of property $i$ in spatial unit $s$ in year $t$. Prices are adjusted to 2015 levels using the Consumer Price Index. wells $s_{i s t}$ is the number of unconventional wells within a given distance buffer at the time of sale, and $I\left(\right.$ well $\left._{i s t}>0\right)$ is a binary variable equal to one if the number of wells is greater than zero (i.e., drilling is present). $X_{i s t}^{\prime}$ is a vector of structural, locational, and environmental explanatory variables. $\gamma_{s}$ are spatial fixed effects; we present specifications using both county and census tract as the spatial unit. $\tau_{t}$ are year fixed effects. Collectively, these fixed effects control for unobserved price determinants across space and time. $\varepsilon_{i s t}$ is the error.

$\beta$ is our coefficient of interest and is interpreted as the impact of having an unconventional well within $r$ miles of the property on residential sale prices. Since we are only analyzing properties with federal mineral ownership, it reflects the marginal value of the environmental costs of having an unconventional well within the given spatial buffer.

Our goal is to define the radius $r$ so that it captures the full spatial extent of negative externalities, but this is a priori unknown. In the spirit of Davis (2011) and more recently Muehlenbachs et al. (2015), we estimate a version of Equation (4) that includes a series of binary variables for different distance bands and seek to determine empirically at what distance the impact falls to a statistical zero.

Figure 3 graphically presents results of a model that regresses log sales price on half mile

\footnotetext{
${ }^{18}$ Phone conversation with Scott McGowan, GIS Coordinator with the Colorado Department of Public Health and Environment.
} 
distance bandwidths out to two miles, as well as property characteristics, year fixed effects, and census tract fixed effects. Results suggest that parameter estimates for the 0-0.5 mile bin and 0.51 mile bin are negative and statistically significant. Coefficient estimates are statistically insignificant beyond one mile. These attenuated, insignificant effects beyond 1 mile are robust across alternative distance bin classifications and are generally similar to those found by Gopalakrishnan and Klaiber (2014) and Muehlenbachs et al. (2015), who use a one mile and a two kilometer buffer, respectively, in their analyses. The similarity in coefficient estimates between the 0-0.5 mile and 0.5-1 mile bins is at first surprising because we would expect greater externalities closer to the drill sight. However, Figure 3 also displays the frequency of observations by distance and we see clustering of observations around 0.5 miles, which is why it is difficult to discern differential impacts less than and greater than 0.5 miles. Going forward, we define $r$ equal to one, and hence wells $s_{\text {ist }}$ is a binary variable equal to 1 if there was a well drilled within one mile of the property before its sale.

\subsection{Assumptions}

There are a number of assumptions needed to interpret our estimates as the valuation of the environmental costs of unconventional oil and gas development. First, we assume that the assignment to treatment - in this case, close proximity to a horizontal well - is exogenous. It is unlikely that split estate owners can strongly dictate whether drilling happens, as the surface owner cannot prevent the mineral estate owner from accessing subsurface resources. Impacted parties can protest the inclusion of a parcel in an oil and gas lease sale (Bureau of Land Management Regulation 43 CFR 3120.1-3), but we were unable to find any protests directly from homeowners in our three study counties. A potential concern is that early oil and gas development could influence the likelihood of severance. In our case, the likelihood of severance is not a concern because of our study area's historical severance of mineral rights.

Second, we assume that property buyers and sellers have full information about local drilling activity and its potential for environmental impact. This is reasonable given the scale of planning and land disturbance associated with well permitting and drilling (e.g., Moran et al. 2015) and significant local discussion regarding the impacts of drilling (e.g., Williams 2008; Lustgarten 2009; Harmon 2014). This region of Colorado has also been the primary site for multiple assessments of the health risks associated with unconventional development (e.g., 
Kassotis et al. 2013). As a result, home buyers are likely conscious of the potential benefits and costs of unconventional oil and gas development.

Third, property buyers and sellers are informed of the property's mineral right status and they understand its ramifications. There has been significant mineral development in western Colorado over the last century (Biewick 2008). As a result, citizens are likely familiar with both oil and gas development and mineral ownership laws. The state legislature also passed a law in 2001 that required pre-transaction notification of the potential for a split estate (Garfield County Energy Advisory Board 2007). There has been much public discussion since 2000 regarding a law that would mandate disclosure of mineral severance prior to all real estate sales. Although this legislation has not been passed due to issues secondary to the disclosure requirement (Moreno 2011), it has been a major point of policy discussion in the state legislature over the study's time period. Additionally, federally owned minerals were never disbursed with the land, so a title search is relatively quick and the information is publically accessible on the Bureau of Land Management's website. ${ }^{19}$

Fourth, we assume that our estimates are not impacted by positive spillover effects of unconventional oil and gas development, including labor opportunities and improved public finances. Although these can be important benefits of local oil and gas development (e.g., Weber 2012; Newell and Rami 2015), these benefits are likely to be received at the regional level and are unlikely to be related to drilling adjacency or to mineral rights ownership.

Fifth, we assume that the financial benefits that a split estate owner can receive from local development are negligible. Landowners who do not own mineral rights are unable to receive lease or royalty payments from on-site production. However, landowners can receive compensation through a surface use agreement, which formally outlines where drilling and surface disturbances can happen on the property. ${ }^{20}$ Surface disturbances may occur from drilling, building access roads, or other infrastructure that occurs on a homeowner's property. To reiterate, no properties in our preferred sample have a horizontal well on their property. Thus, it is unlikely that they have surface use agreements in place and are thus effecting our estimated

\footnotetext{
${ }^{19}$ We relax this assumption in Table 6, where we include observations with unknown mineral ownership.

${ }^{20}$ Matthew Sura, an oil and gas lawyer based in Colorado, stated that surface use agreement payments have increased over time due to surface owner complaints. Some companies in Colorado pay as high as $\$ 10,000$ per well. It is unclear how common this practice is, but this value is still considerably lower than what can be expected from royalty and lease signing bonuses.
} 
valuation of the environmental costs of drilling.

\section{Results}

\subsection{Main Results}

In Table 3, we present results that estimate the parameters of Equation (4), defining wells $_{i s t}$ as the number of unconventional drill sites within one mile of the property at the time of sale. We present four model specifications that sequentially add more control variables to the model. Column 1 only includes property and location variables (i.e., number of bedrooms, distance to closest municipality), Column 2 adds year fixed effects, Column 3 adds county fixed effects, and Column 4 replaces county fixed effects with census tract fixed effects. Across columns, the coefficient on proximity ranges from -0.211 to -0.362 and is always statistically significantly different from zero. The coefficient increases in magnitude substantially when year fixed effects are included, which is intuitive given that drilling (and hence treatment) is correlated with time. The coefficient is stable across Columns 2-4. Our preferred model is Column 4 that includes both year and tract fixed effects. This specification indicates that houses within one mile of unconventional drilling sell for $34.8 \%$ less than houses further away, all else equal. This discount for proximity when multiplied by the average house price of $\$ 183,300$ translates to price reduction of $\$ 63,788$. Converting this into an annual impact using a 30-year mortgage and a $5 \%$ interest rate yields $\$ 3,952$, which is our best estimate of the annual external impacts of unconventional oil and gas development.

\subsection{Robustness checks}

In Table 4, we test for the robustness of this general result across alternative specifications and subsets of the data. In Column 1, we include an additional control variable, which is the number of vertical (conventional) oil and gas wells drilled within a mile of a property between 1980 and 1999. One concern with our main results is that past conventional drilling is likely correlated with unconventional drilling, and thus if there is a negative impact on prices of past drilling, our estimates in Table 3 could be misattributing the variation from past drilling to current drilling. Since recent vertical well development may be an exploratory precursor to later horizontal well development, we use pre-2000 data to avoid potential 
endogeneity issues. In Column 2, we restrict our sample to only properties that have less than 1 acre of land. This test stems from the concern that most of our treated properties are found in a single subdivision. If the price determinants for those properties are different than those on larger lots, our estimated treatment effect could be biased. Column 3 restricts the sample to be within 10 miles of an eventual unconventional well site. One concern with our full sample used in Table 3 is that some observed sales are far from drilling and may be a poor control group. By restricting the spatial distance, we hope to mitigate any bias that results from distant control observations. In Column 4, we estimate a repeat sales model and replace tract fixed effects with property-level fixed effects, which better control for unobservable characteristics that could be correlated with proximity to drilling.

In Column 5 and 6, we develop a model that allows both for an average effect of any wells (similar to our main specification) and a marginal effect for each additional well. Specifically, we estimate the following model in Equation (5):

(5) $\ln \left(p_{\text {ist }}\right)=\beta \cdot I\left(\right.$ wells $\left._{\text {ist }}>0\right)+\sigma \cdot I\left(\right.$ well $\left._{\text {ist }}>0\right) \cdot\left(\right.$ well $_{\text {ist }}-\overline{\text { wells }} \mid$ well $\left.s_{\text {ist }}>0\right)$ $+\mathrm{X}_{\mathrm{ist}}^{\prime} \delta+\gamma_{s}+\tau_{t}+\varepsilon_{i s t}$

where $\beta$ is the effect of a house being within one mile of one or more wells at the time of sale and $\sigma$ is the marginal effect of a single well within one mile conditional on there being at least one well. We subtract the conditional mean (16.8) from the continuous measure so that $\beta$ reflects the average effect of proximity.

The coefficient estimates of the average effect of any wells in proximity to a property, across these six columns, are largely consistent with the main results. Magnitudes range from 0.316 to -0.437 and all estimates are statistically significant. From Columns 5 and 6 , we estimate the additional effect of a well to range from -0.018 to -0.017 . Extrapolating these results indicates that the first well drilled within one mile decreases housing prices by approximately $10.0 \%$ (Column 5) and $16.8 \%$ (Column 6), both of which are substantially larger than the per well effect indicating strong non-linearities. However, given our small sample size, we are uncomfortable putting too much stock into the extrapolation. We hypothesize that there may be even more interesting non-linearities at play, but this is not the paper to estimate them. In sum, Table 4 indicates that our estimates of the effect of drilling with one mile of a residential 
property are largely robust to alternative specifications and subsets of the data. ${ }^{21}$

\subsection{Matching analysis}

In this section, we shift to a matching approach in order to better control for observable differences between our control and treatment groups (e.g., Abbott and Klaiber 2013; Ghanem and Zhang 2014; Ferraro et al. 2015). The main goal of matching is to avoid the issue of selection bias and to create valid treatment-control comparisons through pairing on observable covariates (e.g., Caliendo and Kopeinig 2008; Angrist and Pischke 2009). This occurs when the estimated relationship between treatment status and outcome is driven by inherent differences in covariate distributions between treatment and control groups.

We use matching to further test the robustness of our regression model results. We first estimate a propensity score model of the probability of treatment as a function of propertyspecific variables:

$$
I\left(\text { well }_{\text {ist }}>0\right)=X_{i s t}^{\prime} \alpha+\varepsilon_{\text {ist }}
$$

Where well $_{i s t}$ is defined as above and $X_{i s t}^{\prime}$ is a vector of structural and locational explanatory variables used in our regression models, along with the number of vertical oil and gas wells drilled within a mile of the property from 1980 to 1999, as in Column 1 of Table 5. Including year and tract fixed effects would be ideal to control for temporal price trends and spatial unobservables, but given our limited sample size these match criteria are infeasible.

The propensity score is calculated using estimated coefficients from Equation (6). We then match treated observation to control observations using nearest neighbor matching with replacement. We match each treatment observation to its closest three control observations (3-1 nearest neighbor matching). We apply a 0.05 caliper on the propensity score. Figure 4 provides the propensity score distributions for our control and treatment groups, pre- versus postmatching, and shows that matching significantly reduces the difference between the distributions. $^{22}$

\footnotetext{
${ }^{21}$ In the online appendix, we provide additional robustness checks. In Table 3A, we find qualitatively similar results when we define our treatment variable as the number of wells drilled within one mile of the property's extent, or when we use a distance bin approach. We also estimate our models in levels, as opposed to logs, and find similar results (Table 4A). In line with the structure of Table 4, we provide additional robustness check in Table 5A. All results from the appendix support our main findings.

${ }^{22}$ Following Rosenbaum and Rubin (1985), Sianesi (2004), and Kassie, Shiferaw, and Muricho (2011), we test the balancing between our matched treatment and control groups through mean standardized differences and the pseudo $\mathrm{R}^{2}$ and likelihood ratio test of joint significance. We find that the mean standardized differences in our variables are
} 
Table 5 presents estimates of the treatment effect for our matching models. In Column 1, we estimate the difference in means between our treated observations and our matched control observations. The estimated difference in $\log$ prices is -0.263 and is statistically significant. In Columns 2-4, we use the matched sample to ensure covariate balance, but we return to a regression framework to account for price dynamics and spatial unobservable variables. Control observations can be used more than once, so we weight each transaction proportional to the number of times it is used in the matching process using weighted least squares. ${ }^{23}$

In Column 2, we control for the estimated propensity score in our regression. The coefficient on proximity is -0.239 , quite similar to the matching estimate. In Column 3 , we add year fixed effects. The coefficient here is -0.437 , which is a substantial increase in magnitude over Columns 1-2. Adding year fixed effects had a similar impact on coefficient magnitude in Table 3. In Column 4, we lastly property characteristics and the resulting coefficient is -0.339 , nearly identical to the main results in Table 3. In conclusion, our matching model improves the similarity of our treated and control observations, but results are similar to the regression models.

\subsection{Quasi Difference-in-Differences Estimates}

The criteria for creating our main sample is ideal for identifying the negative externalities of shale development. However, our estimated treatment effect relies primarily on properties within a single census tract of Garfield County. The property sales in this census tract are primarily made up of the combined towns of Battlement Mesa, CO and Parachute, $\mathrm{CO}$, alongside other groups of properties both upstream and downstream of the Colorado River. The treated federal mineral properties are relatively small in lot size and are located in one subdivision within the combined town (Treated/Control: 92/191 observations, respectively). The concern with this distribution of treated properties is that if there is something unobservable about this town that leads to differential price trends relative to other areas of our sample counties, then our cross-sectional analysis will produce biased estimates.

To address this shortcoming, we estimate a quasi difference-in-differences model using only comparable properties in the census tract that includes Battlement Mesa and Parachute. In

reduced, our Pseudo- $\mathrm{R}^{2}$ is reduced, and that the joint significance of the matching covariates is rejected, postmatching. These results are available in Table 6A in the online appendix.

${ }^{23}$ All transactions not matched to another observation are given zero weight. 
this model, we are comparing price changes of federal mineral properties (treated) to unknown mineral rights properties (control) from the time before drilling began to the time after drilling.

$$
\begin{gathered}
\ln \left(p_{\text {ist }}\right)=\beta_{1} \cdot I\left(\text { wells }_{\text {ist }}>0\right)+\beta_{2} \cdot \text { FederalMinerals }+\beta_{3} \cdot I\left(\text { wells }_{\text {ist }}>0\right) \\
* \text { FederalMinerals }+X_{i s t}^{\prime} \delta+\tau_{t}+\varepsilon_{i s t}
\end{gathered}
$$

The parameter of interest is on the interaction term (i.e., $\beta_{3}$ ), which indicates the impact of nearby well development for properties with federal mineral ownership, relative to properties with unknown mineral ownership. In addition to using only properties in this single census tract discussed above, we exclude properties that are more rural or have different on-property amenities by only using those properties with parcels that are less than 1 acre in size. This could be important for identification, as most of the split estate properties in this area are small acreage properties. This approach also restricts our sample to residential areas that are relatively close in distance to each other. In Column 2, we use a repeat sales model with the same restrictions on acreage. The model also includes the same covariates $X$ as in Equation 4 and year fixed effects.

Our approach in Table 6 relies on similar pre-treatment trends between both treated and non-treated areas to make valid inferences. This approach uses control properties that are similar in terms of location and structural characteristics to our treated properties. Thus, any time trend that influences the properties in this census tract will be captured by the control properties. The spatial distribution of our treated properties may increase the risk of idiosyncratic time varying shocks related to changes in neighborhoods overtime. However, subdivisions are relatively close in distance to each other in this town. Thus, any unrelated shocks to a subdivision correlated to shale drilling should attenuate our estimate as we would expect these shocks to affect nearby neighborhoods in the same town.

In Table 6, we generally find similar estimates to those found in Tables 3 through 5, though slightly smaller. In Column 1, we estimate the impact of well drilling on split estate properties is -0.282 . Our repeat sales model, in Column 2, also finds a similar estimate of $0.281 .^{24} \mathrm{We}$ do not interpret the estimates of treatment for properties with non-federal mineral ownership because of the many issues in interpretation of unknown mineral rights discussed in

\footnotetext{
${ }^{24}$ We also estimate a more traditional difference-in-differences model and find similar results.
} 
our conceptual framework.

\section{Conclusion}

In this paper, we quantify the negative externalities associated with unconventional extraction of oil and gas using hedonic valuation of residential properties. We exploit the early $20^{\text {th }}$ century homestead act extensions, including the Stock-Raising Homestead Act of 1916, to identify properties that do not have mineral rights. These properties cannot benefit financially from lease payments or royalties, and in our sample likely do not have surface use agreements. Thus, our proximity effect estimates isolate the external costs of unconventional oil and gas development. This approach resolves a significant issue in the valuation of unconventional oil and gas development, which has caused uncertainty in the interpretation of estimates from previous studies.

The results of our hedonic analysis suggest that houses within one mile of an unconventional drill site sell for $34.8 \%$ less than comparable properties without proximate drilling. This discount translates to a price reduction of $\$ 63,788$, which equals $\$ 3,952$ when annualized by a 30-year mortgage and a 5\% interest rate. We interpret this price difference as the household valuation of the external environmental and health costs associated with proximity to unconventional oil and gas development.

Our findings are $60 \%$ larger in magnitude than the largest existing negative estimate. Our study's ability to identify split estate properties is likely the cause of this disparity. However, it is important to understand this effect in the context of some of the gains that can be received by homeowners who do own their property's mineral rights. We used Drillinginfo's production and lease data to obtain a rough estimate for the potential royalties received by those who do own minerals. From 2000 to $2012^{25}$ in our study area, the average royalty rates were $14.7 \%$. In the first five years of a well's lifetime in our study area, average production is 476 million cubic feet of natural gas and 1,980 barrels of oil. ${ }^{26}$ Given wellhead prices at $\$ 4,718 / \mathrm{mmcf}$ of natural gas ${ }^{27}$

\footnotetext{
25 Timeline based on the availability of lease data from Drillinginfo.

${ }^{26}$ These estimates are based on only those wells producing from 2000 to 2015 for at least five years. Wells that only produced in 2011 or beyond are not included in this estimate. We focus our analysis on only the first five years given the steep decline curves associated with unconventional oil and gas development.

${ }^{27}$ Natural gas wellhead price for Colorado (dollars per thousand cubic feet). Average annual value from 2000 to 2010 .
} 
and $\$ 58.70 /$ barrel of oil ${ }^{28}$, the undiscounted level of royalty payments within the first five years of well production is $\$ 347,213$. At the median royalty rate of $12.5 \%$ (the recommended rate by the Colorado Land Board at the time of our study), the value of the payment stream is $\$ 295,249$. These estimates should be considered alongside broader work by Brown, Fitzgerald, and Weber (2016), which estimate that over $\$ 39$ billion dollars in royalties were generated from oil and gas production from the United States' six largest shale plays in 2014. What each property owner would receive from this estimate would be a function of the owner's proportional acreage within the area of the drilling unit and their ability to negotiate the royalty rate. Given this general projection, we believe that royalty payments may be very significant for those property owners that retain mineral ownership. The lease payments and future royalty streams may be large enough to compensate for environmental and health risks.

Our findings can inform the United States and other countries in how to proceed with energy development. The suite of energy options available to consumers have benefits and costs that are received at global, regional, and local levels, in all stages of development from extraction to ultimate consumption. Our estimates of the local external costs of unconventional oil and gas development should be considered with those incurred from other forms of energy production, including coal-fired power plants (Davis 2011), wind turbines (Lang, Opaluch, and Sfinarolakis 2014; Gibbons 2015), and nuclear power facilities (Gawande, Jenkins-Smith, and Yuan 2013). For areas that allow local regulation of oil and gas development, optimal local policy responses to unconventional oil and gas development should consider these results alongside others which find positive valuations of development (Boslett et al. 2016), employment effects (Weber 2011), and income effects (e.g., Feyrer, Mansur, and Sacerdote 2015).

Understanding mineral rights ownership and its impacts is important beyond the housing market. The level of local mineral ownership may have long-term impacts on how drilling influences long-term economic development in local communities. Research has found that oil and gas development can have positive (Michaels 2011) and negative (Jacobsen and Parker 2016) long-term economic effects on local communities. High levels of local mineral rights severance may dampen the potential for local investment in infrastructure and capital since royalty and lease bonus payments are directed outside of drilling areas. Local policy-makers may

\footnotetext{
${ }^{28}$ Domestic Crude Oil First Purchase Prices by Area for Colorado (dollars per barrel). Average annual value from
} 2000 to 2015. 
be further incentivized to regulate development in such a way as to reduce both the external costs of development and encourage investment in the local community. Future research should explore how levels of local mineral ownership relate to the long-term economic impacts of oil and gas development.

Lastly, prior hedonic valuation research provides great insight on local valuation of unconventional oil and gas development, especially on its perceived water quality risks. While we caution extrapolation of our result based on the small sample size, external validity outside of the United States is limited in previous studies because private citizens in European and many other countries do not own subsurface minerals which makes this natural experiment applicable to other countries. Our study may be relevant and applicable to a broader geographic area than Colorado and may provide a better metric for external costs of unconventional oil and gas exploration in other countries because it explicitly accounts for the critical issue of mineral rights ownership. 


\section{Works Cited}

Abbott, Joshua K., and H. Allen Klaiber. 2013. The value of water as an urban club good: A matching approach to community-provided lakes. Journal of Environmental Economics and Management 65 (2): 208-224.

Allen, Douglas. 2011. Homesteading and property rights; or, how the West was really won. Journal of Law and Economics XXXIV: 1-23.

Anderson, Terry L., and Peter J. Hill. 1990. The race for property rights. The Journal of Law \& Economics 33 (1): 177-197.

Angrist, Joshua D., and Jörn-Steffen Pischke. 2009. Mostly Harmless Econometrics: An Empiricist's Companion. Princeton, New Jersey, USA: Princeton University Press.

Bennett, Ashley, and John Loomis. 2015. Are housing prices pulled down or pushed up by fracked oil and gas wells? A hedonic price analysis of housing values in Weld County, Colorado. Society \& Natural Resources 28 (11): 1168-1186.

Biewick, Laura H. 2008. Areas of Historical Oil and Gas Exploration and Production in the United States. United States Geological Survey.

Boslett, Andrew, Todd Guilfoos, and Corey Lang. 2016. Valuation of expectations: A hedonic study of shale gas development and New York's moratorium. Journal of Environmental Economics and Management 77: 14-30.

Brasier, Kathryn J., Matthew Filteau, Diane K. McLaughlin, Jeffrey Jacquet, Richard C. Stedman, Tim W. Kelsey, and Stephen J. Goetz. 2011. Residents' perceptions of community and environmental impacts from development of natural gas in the Marcellus shale: A comparison of Pennsylvania and New York cases. Journal of Rural Social Sciences 26 (1): 32-61.

Brasier, Kathryn J., Diane K. McLaughlin, Danielle Rhubart, Richard C. Stedman, Matthew R. Filteau, and Jeffrey Jacquet. 2013. Risk perceptions of natural gas development in the Marcellus shale. Environmental Practice 15 (2): 108-122.

Brown, Jason P., Timothy Fitzgerald, and Jeremy G. Weber. 2016. Capturing rents from natural resource abundance: Private royalties from U.S. onshore oil \& gas production. Resource \& Energy Economics 46: 23-38.

Bureau of Land Management. 2003. Permitting Oil and Gas on Split Estate Lands and Guidance for Onshore Oil and Gas Order No. 1. Instruction Memorandum No. 2003-131.

Bureau of Land Management. 2006. Split estate: Private surface / public minerals - What does it mean to you? Presentation, Bureau of Land Management, U.S. Department of Interior. 
Bureau of Land Management. 2007. Split estate: Rights, responsibilities, and opportunities. Community publication, BLM/WO/GI-06/022+3161/REV 07, Bureau of Land Management, U.S. Department of Interior.

Caliendo, Marco, and Sabine Kopeinig. 2008. Some practical guidance for the implementation of propensity score matching. Journal of Economic Surveys 22 (1): 31-72.

Collins, Alan, and Kofi Nkansah. 2015. Divided rights, expanded conflict: Split estate impacts on surface owner perceptions of shale gas drilling. Land Economics 91 (4): 688-703.

Davis, Charles. 2014. Substate federalism and fracking policies: Does state regulatory authority trump local land use autonomy? Environmental Science \& Technology 48: 8397-8403.

Davis, Lucas. 2011. The effect of power plants on local housing values and rents. The Review of Economics and Statistics 93 (4): 1391-1402.

Delgado, Michael, Todd Guilfoos, and Andrew Boslett. 2016. The cost of unconventional gas extraction: A hedonic analysis. Resource and Energy Economics 46: 1-22.

Doran, Kevin L., and Angela M. Cifor. 2012. Does the federal government own the pore space under private lands in the west? Implications of the Stock-Raising Homestead Act of 1916 for geologic storage of carbon dioxide. Environmental Law 42: 527-548.

Edwards, Richard. 2009. Changing perceptions of homesteading as a policy of public domain disposal. Great Plains Quarterly 29 (3): 179-202.

Ferraro, Paul J., Merlin M. Hanauer, Daniela A. Miteva, Joanna L. Nelson, Subhrendu K. Pattanayak, Christoph Nolte, and Katharine R.E. Sims. 2015. Estimating the impacts of conservation on ecosystem services and poverty by integrating modeling and evaluation. Proceedings of the National Academy of Sciences 112 (24): 7420-7425.

Feyrer, James, Erin T. Mansur, and Bruce Sacerdote. 2015. Geographic dispersion of economic shocks: Evidence from the fracking revolution. Working Paper No. 21624, The National Bureau of Economic Research.

Fitzgerald, Timothy. 2010. Evaluating split estates in oil and gas leasing. Land Economics 86 (2): 294-312.

Fitzgerald, Timothy. 2013. The role of ownership in environmental performance: Evidence from coalbed methane development. Environmental Management 52 (6): 1503-1517.

Fitzgerald, Timothy. 2014. Importance of mineral rights and royalty interests for rural residents and landowners. Choices 29 (4): 1-7.

Fleck, Ernest R. 1974. Severed mineral interests. North Dakota Law Review 51: 369-385. 
Garfield County Energy Advisory Board. 2007. Community guide: Understanding natural gas development.

Gates, Paul W. 1968. History of Public Land Law Development. Washington, D.C., USA: Public Land Law Review Commission.

Gates, Paul W. 1977. Homesteading in the high plains. Agricultural History 51 (1): 109-133.

Gawande, Kishore, Hank Jenkins-Smith, H., and May Yuan. 2013. The long-run impact of nuclear waste shipments on the property market: Evidence from a quasi-experiment. Journal of Environmental Economics and Management 65 (1): 56-73.

Gény, Florence. 2010. Can unconventional gas be a game changer in European gas markets? NG 46, Oxford Institute for Energy Studies.

Ghanem, Dalia, and Junjie Zhang. 2014. 'Effortless Perfection:' Do Chinese cities manipulate air pollution data? Journal of Environmental Economics and Management 68 (2): 203-225.

Gibbons, Stephen. 2015. Gone with the wind: Valuing the visual impacts of wind turbines through house prices. Journal of Environmental Economics and Management 72: 177-196.

Gopalakrishnan, Sathya, and H. Allen Klaiber. 2014. Is the shale energy boom a busty for nearby residents? Evidence from housing values in Pennsylvania. American Journal of Agricultural Economics 96 (1): 43-66.

Hancock, Laura. 2014. Wyoming committee endorses split-estate bonding hike to $\$ 10,000$. Casper Star-Tribune, February 17.

Hardy, Kirsten, and Timothy W. Kelsey. 2015. Local income related to Marcellus shale activity in Pennsylvania. Community Development 46 (4): 329-340.

Harmon, Gary. 2014. Most gas drilling permit applications in Colorado for non-federal land. Grand Junction Daily Sentinel, February 16.

Harrison, Sylvia L. 1989. Disposition of the mineral estate on United States public lands: A historical perspective. Public Land Law Review 10 (131): 131-156.

Hawkins, Sarah J., Ronald R. Charpentier, Christopher J. Schenk, Heidi M. Leathers-Miller, Timothy R. Klett, Michael E. Brownfield, Tom M. Finn, Stephanie B. Gaswirth, Kristen R. Marra, Phuong A. Le, Tracey J. Mercier, Janet K. Pitman, and Marilyn E. Tennyson. 2016. Assessment of continuous (unconventional) oil and gas resources in the Late Cretaceous Mancos Shale of the Piceance Basin, Uinta-Piceance Province, Colorado and Utah, 2016. U.S. Geological Survey Fact Sheet 2016-330.

Hill, Drake D., and P. Jaye Rippley. 2004. The split estate: Communication and education versus legislation. Wyoming Law Review 4 (2): 585-605. 
Hill, Elaine. 2013. Oil and gas development and infant health in Colorado. University of Rochester Working Paper.

Holmes, Michael, Antony M. Holmes, Dominic I. Holmes. 2005. Petrophysical analysis of Piceance Basin tight gas sandstones, NW Colorado, to distinguish wet sands from gas-bearing sands, and to categorize rock quality variation by incorporating capillary pressure interpretations. RMAG 2005 Guidebook.

Jacobsen, Grant D., and Dominic P. Parker. 2016. The economic aftermath of resource booms: Evidence from boomtowns in the American West. The Economic Journal 126 (593): 1092-1128.

James, Alexander, and Jasmine James. 2016. A canary near a gas well: Gas booms and housingmarket busts in Colorado. Working Paper.

Johnson, John E. 1998. Gerrity Oil \& Gas Corp. v. Magness: Colorado's furtive shift toward accommodation in the surface-use debate. Tulsa Law Review 33 (3): 943-957.

Kassie, Menale, Bekele Shiferaw, and Geoffrey Muricho. 2011. Agricultural technology, crop income, and poverty alleviation in Uganda. World Development 39 (10): 1784-1795.

Kassotis, Christopher D., Donald E. Tillitt, J. Wade Davis, Annette M. Hormann, and Susan C. Nagel. 2013. Estrogen and androgen receptor activities of hydraulic fracturing chemicals and surface and ground water in a drilling dense region. Endocrinology 155 (3): 897-907.

Kelly-Detwiler, Peter. 2013. Shale leases: Promised land. Forbes, January 3.

Kelsey, Timothy W., Alex Metcalf, and Rodrigo Salcedo. 2012. Marcellus shale: Land ownership, local voice, and the distribution of lease and royalty dollars. Pennsylvania State University. Center for Economic and Community Development Research Paper Series.

Krupnick, Alan J., and Isabel Echarte. 2017. Housing Market Impacts of Unconventional Oil and Gas Development. Resources for the Future.

Kulander, Christopher S. 2013. Common law aspects of shale oil and gas development. Idaho Law Review 49: 367-398.

Laitos, Jan, Sandi Zellmer, and Mary C. Wood. 2006. Natural Resource Law. Saint Paul, Minnesota, USA: West Academic.

Lang, Corey, James J. Opaluch, and George Sfinarolakis. 2014. The windy city: Property value impacts of wind turbines in an urban setting. Energy Economics 44: 413-421.

Loomis, John. 2002. Integrated Public Lands Management: Principles and Applications to National Forests, Parks, Wildlife Refuges, and BLM Lands. New York, NY: Columbia University Press 
Lustgarten, Abrahm. 2009. Colorado study links methane in water to drilling. ProPublica, April 22.

McKenzie, Lisa M., Ruixin Guo, Roxana Z. Witter, David A. Savitz, Lee S. Newman, and John L. Adgate. 2014. Birth outcomes and maternal residential proximity to natural gas development in rural Colorado. Environmental Health Perspectives 122 (4): 412-417.

Michaels, Guy. 2011. The long term consequences of resource-based specialization. The Economic Journal 121 (551): 31-57.

Moran, Matthew D., A. Brandon Cox, Rachel L. Wells, Chloe C. Benichou, and Maureen R. McClung. 2015. Habitat loss and modification due to gas development in the Fayetteville Shale. Environmental Management 55 (6); 1276-1284.

Moreno, Ivan. 2011. Bill aims to inform homeowners of mineral rights. CBS Denver, December 6.

Muehlenbachs, Lucija, Elisheba Spiller, and Christopher Timmins. 2015. The housing market impacts of shale gas development. The American Economic Review 105 (12): 3633-3359.

Newell, Richard G., and Daniel Raimi. 2015. Oil and gas revenue allocation to local governments in eight states. Working Paper No. 21615, National Bureau of Economic Research Working Paper, Cambridge, MA.

Olmstead, Sheila, Lucija A. Muehlenbachs, Jhih-Shyang Shih, Ziyan Chu, and Alan J. Krupnick. 2013. Shale gas development impacts on surface water quality in Pennsylvania. Proceedings of National Academy of Sciences 110 (13): 4962-4967.

Osborn, Stephen G., Avner Vengosh, Nathaniel R. Warner, and Robert B. Jackson. 2011. Proceedings of the National Academy of Sciences 108 (20): 8172-8176.

Pender, John L., Jeremy G. Weber, and Jason P. Brown. 2014. Sustainable rural development and wealth creation: Five observations based on emerging energy opportunities. Economic Development Quarterly 28 (1): 73-86.

Powder River Basin Resource Council. 2010. The state of the split estate. A landowner perspective: Five years after passage of the Wyoming Split Estate Statute. Policy report.

Rahm, Brian G., and Susan J. Riha. 2012. Toward strategic management of shale gas development: Regional, collective impacts on water resources. Environmental Science \& Policy 17: $12-23$.

Railroad Commission of Texas. 2015. Oil \& gas exploration and surface ownership. General information document. 
Rosen, Sherwin. 1974. Hedonic prices and implicit markets: Product differentiation in pure competition. The Journal of Political Economy 82 (1): 34-55.

Rosenbaum, Paul R., and Donald B. Rubin. 1985. Constructing a control group using multivariate matched sampling methods that incorporate the propensity score. The American Statistician 39 (1): 33-38.

Sianesi, Barbara. 2004. An evaluation of the Swedish system of active labour market programmes in the 1990s. The Review of Economics and Statistics 86 (1): 133-155.

Stevens, Paul. 2010. The 'Shale Gas Revolution': Hype and Reality. London, UK: Chatham House Report.

Tanke, Tony J., and C. Putz. 1982. Use of lands patented under the Stock-Raising Homestead Act for construction and operation of geothermal power plants. Natural Resources Lawyer 14: 725-740.

Telluride Daily Planet. 2005. Property owners at odds with BLM oil and gas leases. April 29.

Verity, Victor H., and Robert J. Young. 1971. Laws and regulations governing mineral rights in New Mexico. New Mexico State, Bureau of Mines and Mineral Resources.

Wang, Zhongmin, and Alan Krupnick. 2013. A retrospective review of shale gas development in the United States: What led to the boom? Resources for the Future. Discussion Paper 13-12.

Watson, Rebecca W. 2008. State surface owner protection laws: Tales of preemption, federalism, and a changing West.

Weber, Jeremy. 2012. The effects of a natural gas boom on employment and income in Colorado, Texas, and Wyoming. Energy Economics 34 (5): 1580-1588.

Weber, Jeremy, J. Wesley Burnett, and Irene M. Xiarchos. 2014. Shale gas development and housing values over a decade: Evidence from the Barnett Shale. Working Paper 14-165, United States Association for Energy Economics.

Weber, Jeremy, and Claudia Hitaj. 2015. What can we learn about shale gas development from land values? Opportunities, challenges, and evidence from Texas and Pennsylvania. Agricultural and Resource Economics Review 44 (2): 40-58.

West, Mary Beth. 1992. Natural resources development on Indian reservations: Overview of tribal, state, and federal jurisdiction. American Indian Law Review 17 (1): 71-98.

Williams, David O. 2008. Garfield County Dems lament energy-industry influence in local races. The Colorado Independent, November 7. 
Wilson, Joe. 2014. Title searches: Proof of mineral rights ownership. Greene County Messenger, November 28. 


\section{Tables \& Figures}

Table 1: Financial benefits and environmental costs of oil and gas development, differentiated by mineral estate ownership classification

\begin{tabular}{lccc}
\hline & $\begin{array}{c}\text { Local Environmental } \\
\text { Costs }\end{array}$ & $\begin{array}{c}\text { Local Financial } \\
\text { Benefits }\end{array}$ & $\begin{array}{c}\text { Valuation of } \\
\text { Proximity }\end{array}$ \\
\hline Unified $\left(M_{i}=1\right)$ & $C$ & $B$ & $C+B$ \\
Split $\left(M_{i}=0\right)$ & $C$ & 0 & $C$ \\
\hline
\end{tabular}


Table 2: Summary statistics

Variable Mean Std. Dev.

Percent of properties with horizontal wells:

within 1 mile

within 2 miles

34.6

within 3 miles

38.2

Number of horizontal wells within 1

16.8

15.8

mile, conditional on existence

Sale price $(\$ 000 \mathrm{~s})$

$183.3 \quad 81.4$

Lot size (acres)

$6.4 \quad 26.7$

Property age (years)

17.8

16.4

Bedrooms

$3.0 \quad 0.7$

Bathrooms

$2.0 \quad 0.6$

Living area (000s of sq. feet)

$\begin{array}{ll}1.6 & 0.7\end{array}$

Distance to municipality (in miles)

$1.8 \quad 3.4$

Percent of parcel in agricultural use

$3.0 \quad 14.4$

Number of vertical wells $<1$ mile

0.9

1.1

Observations

783

Notes: Sample is comprised of only properties with federal mineral rights. We received residential property transaction, structural, and parcel data from Garfield, Mesa, and Rio Blanco county assessment and geographic information systems (GIS) offices. We also received location data for all horizontal wells drilled from 2000 to 2015 and all vertical wells drilled from 1980 to 1999 in Colorado from Drillinginfo. We calculated the percentage of each property in an agricultural use using National Land Cover Dataset 2001 data. We calculated the distance to the closest municipality using U.S. Census Bureau TIGER data from 2010. 
Table 3: The effect of unconventional development on the residential properties with federal mineral ownership

\begin{tabular}{lcccc}
\hline \hline & $(1)$ & $(2)$ & $(3)$ & $(4)$ \\
\hline I(wells $>$ 0) & $-0.211 * * *$ & $-0.343 * * *$ & $-0.362 * * *$ & $-0.348 * * *$ \\
& $(0.033)$ & $(0.025)$ & $(0.064)$ & $(0.059)$ \\
R-Squared & & & & \\
\hline Property \& Location Vars. & 0.397 & 0.499 & 0.513 & 0.547 \\
Year FE & $\mathrm{Y}$ & $\mathrm{Y}$ & $\mathrm{Y}$ & $\mathrm{Y}$ \\
County FE & $\mathrm{N}$ & $\mathrm{Y}$ & $\mathrm{Y}$ & $\mathrm{Y}$ \\
Tract FE & $\mathrm{N}$ & $\mathrm{N}$ & $\mathrm{Y}$ & $\mathrm{N}$ \\
\hline
\end{tabular}

Notes: Observations represent single family residential properties sold from 2000 to early 2015 in Garfield, Mesa, and Rio Blanco counties $(\mathrm{N}=783)$. We truncate the data set to exclude the 5 and 95 percentiles of sale price. The dependent variable is the natural $\log$ of sale price (CPI-adjusted to 2014 values). Property variables include quadratics of \# of bedrooms and bathrooms, parcel acreage, property finished living area, and property age. Location variables include quadratics of distance to the closest municipality and the percentage of the property in an agricultural use. Census tracts are based on U.S. Census 2010 boundaries. Standard errors are shown in parentheses and are estimated using tract-level cluster-robust inference: $* * *$ indicates statistical significance at the $1 \%$ level. 
Table 4: Robustness checks and extensions

\begin{tabular}{|c|c|c|c|c|c|c|}
\hline & (1) & $(2)$ & (3) & (4) & $(5)$ & $(6)$ \\
\hline & $\begin{array}{c}\text { Vertical } \\
\text { well } \\
\text { control }\end{array}$ & $\begin{array}{c}\text { Acreage } \\
\text { Restriction } \\
<1 \text { acres }\end{array}$ & $\begin{array}{c}\text { Well } \\
\text { Distance } \\
\text { Restriction } \\
<10 \text { miles } \\
\end{array}$ & $\begin{array}{c}\text { Repeat } \\
\text { Sales }\end{array}$ & $\begin{array}{c}\text { Add } \\
\text { Intensity }\end{array}$ & $\begin{array}{c}\text { Repeat } \\
\text { Sales } \\
+ \\
\text { Intensity }\end{array}$ \\
\hline $\mathrm{I}($ wells $>0)$ & $\begin{array}{c}-0.348 * * * \\
(0.0596)\end{array}$ & $\begin{array}{c}-0.324 * * * \\
(0.069)\end{array}$ & $\begin{array}{c}-0.316^{* * *} \\
(0.065)\end{array}$ & $\begin{array}{c}-0.381 * * * \\
(0.076)\end{array}$ & $\begin{array}{c}-0.384 * * * \\
(0.039)\end{array}$ & $\begin{array}{c}-0.437 * * * * \\
(0.086)\end{array}$ \\
\hline $\mathrm{I}($ wells $>0) *$ wells & & & & & $\begin{array}{c}-0.018 * * * \\
(0.003)\end{array}$ & $\begin{array}{c}-0.017 * * * * \\
(0.003)\end{array}$ \\
\hline Observations & 783 & 574 & 638 & 522 & 783 & 522 \\
\hline R-Squared & 0.560 & 0.596 & 0.579 & 0.798 & 0.584 & 0.816 \\
\hline Property \& Location Vars. & $\mathrm{Y}$ & $\mathrm{Y}$ & $\mathrm{Y}$ & $\mathrm{N}$ & $\mathrm{Y}$ & $\mathrm{N}$ \\
\hline Year FE & $\mathrm{Y}$ & Y & Y & Y & $\mathrm{Y}$ & Y \\
\hline Tract FE & $\mathrm{Y}$ & Y & Y & $\mathrm{N}$ & $\mathrm{Y}$ & $\mathrm{N}$ \\
\hline Property FE & $\mathrm{N}$ & $\mathrm{N}$ & $\mathrm{N}$ & $\mathrm{Y}$ & $\mathrm{N}$ & $\mathrm{Y}$ \\
\hline
\end{tabular}

Notes: In Column 1, we include a control for the number of vertical (conventional) oil and gas wells drilled from 1980 to 1999 within one mile of the property. In Columns 2 and 3, we restrict our sample to only those observations that are less than 1 acre and 10 miles of a well drilled pre or post-sale, respectively. In Column 4, we estimate a repeat sales model using only properties that transacted more than once from 2000 to 2015. In Column 5, we include a continuous measure of the number of wells within one mile of a property. We transform this variable by subtracting the mean number of wells conditional on the number of wells being greater than zero (16.8). This specification identifies both an average effect of proximity and a marginal effect of an additional well. Column 6 estimates the Column 5 specification using a repeat sales model. Standard errors are shown in parentheses and are estimated using tract-level cluster-robust inference: $* * *$ indicates statistical significance at the $1 \%$ level. 
Table 5: The effect of unconventional development on split estate properties using matching techniques

\begin{tabular}{lccccc}
\hline \hline & \multicolumn{2}{c}{$\begin{array}{c}\text { Nearest Neighbor } \\
\text { Matching }\end{array}$} & & \multicolumn{3}{c}{ Weighted Regression } \\
\cline { 2 - 3 } \cline { 5 - 6 } \cline { 5 - 6 } & $(3-1)$ & & Only P.S. & + Year FE & $\begin{array}{c}\text { + Property } \\
\text { Variables }\end{array}$ \\
\hline I(wells $>0)$ & $(1)$ & $(2)$ & $(3)$ & $(4)$ \\
R-Squared & $-0.263 * * *$ & & $-0.239 * * *$ & $-0.437 * * *$ & $-0.333^{* * *}$ \\
\hline
\end{tabular}

Notes: In Columns 1, we use nearest neighbor matching (3 - 1) and match on the \# of bedrooms and bathrooms, living area, property age, and acreage, as well as the distance to the closest municipality, the percentage of the property in an agricultural use, and the number of vertical wells drilled within a mile from 1980 to 1999. We match with replacement and with a caliper of 0.05. In Column 2 through 4, we use our treatment observations and matched control observations from our Nearest Neighbor matching in Column 1 and estimate weighted regression models (in line with Equation 1 and Table 3). We weight based on the number of times each control observation was matched to a treatment observation. In Column 2, we only control for the estimated propensity score. In Column 3, we add year fixed effects. In Column 4, we add the structural and locational variables defined above. Standard errors are shown in parentheses and are estimated using tract-level clusterrobust inference: $* *$ and $* * *$ indicate statistical significance at the $5 \%$ and $1 \%$ levels, respectively. 
Table 6: The effect of unconventional development on the residential properties with federal and unknown mineral ownership

\begin{tabular}{lcc}
\hline \hline & $(1)$ & $(2)$ \\
\hline I(wells $>0)$ & $-0.091^{* *}$ & $-0.185^{* * *}$ \\
& $(0.046)$ & $(0.069)$ \\
Federal Mineral Ownership & $-0.097^{* *}$ & - \\
& $(0.046)$ & - \\
I(wells $>0) *$ Federal Mineral Ownership & $-0.282^{* * *}$ & $-0.281^{* * *}$ \\
& $(0.066)$ & $(0.086)$ \\
Observations & 1,683 & 1,464 \\
R-Squared & 0.232 & 0.567 \\
\hline Property \& Location Vars. & $\mathrm{Y}$ & $\mathrm{N}$ \\
Year FE & $\mathrm{Y}$ & $\mathrm{Y}$ \\
Property FE & $\mathrm{N}$ & $\mathrm{Y}$ \\
\hline
\end{tabular}

Notes: We truncate the data set to exclude the 5 and 95 percentiles of sale price. The dependent variable is the natural log of sale price (CPI-adjusted to 2014 values). In both columns we restrict our sample to include only those properties in the census tract with the bulk of our treated split estate properties. In Column 1 we restrict properties to have less than 1 acre of land while in Column 2 we restrict to only properties with multiple sales. Property variables include quadratics of \# of bedrooms and bathrooms, parcel acreage, property finished living area, and property age. Location variables include quadratics of distance to the closest municipality and the percentage of the property in an agricultural use. Census tracts are based on U.S. Census 2010 boundaries. Standard errors are shown in parentheses and are estimated using tract-level cluster-robust inference: *, **, and $* * *$ indicate statistical significance at the $10 \%, 5 \%$, and $1 \%$ levels, respectively. 
Figure 1: Map of unconventional oil and gas development in Colorado

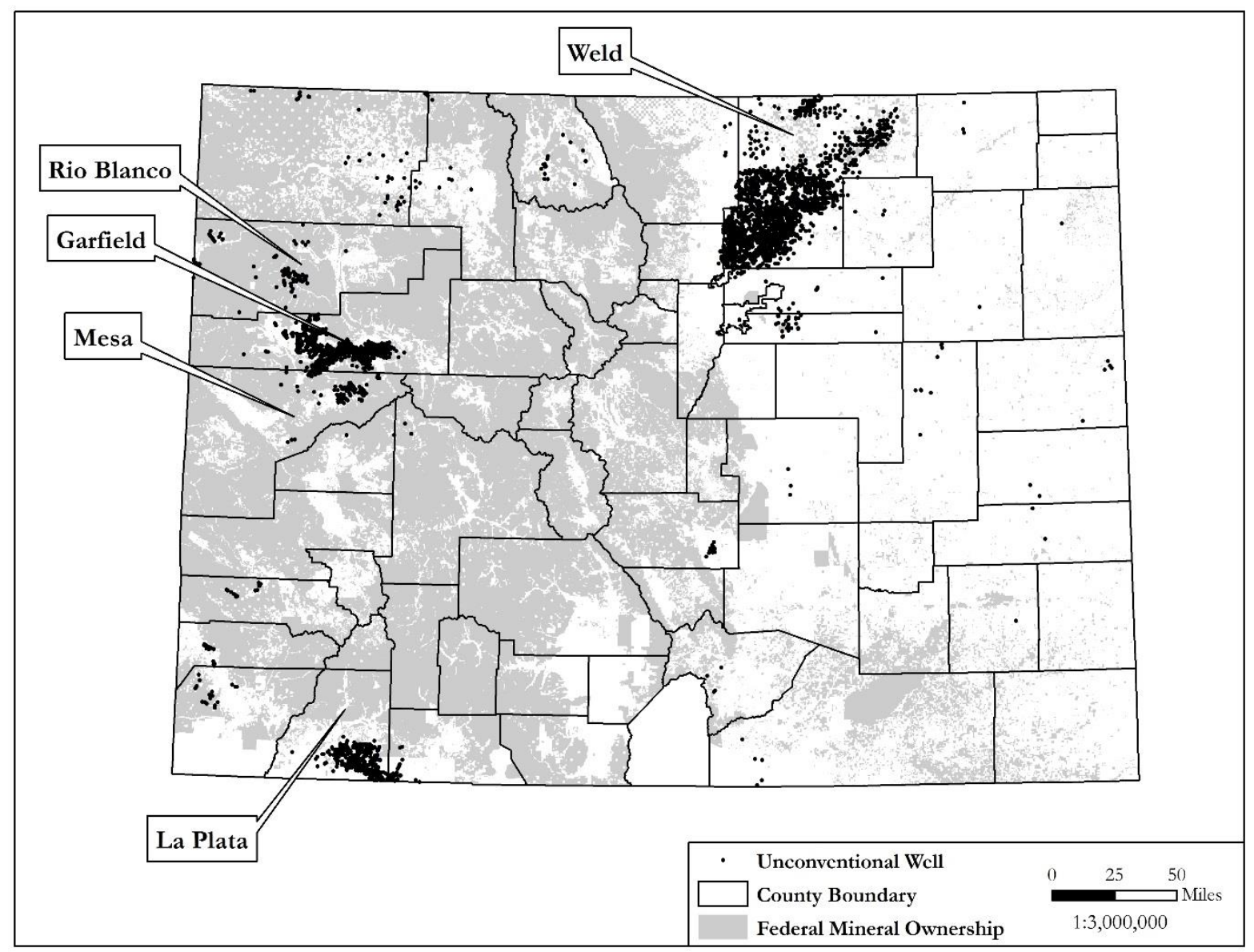

Notes: Unconventional well location data was provided by Drillinginfo. Data on federal mineral ownership is from the Bureau of Land Management Colorado Office's GIS department. 
Figure 2: Large scale map of a subset of horizontal wells and property transactions with different mineral estate classifications

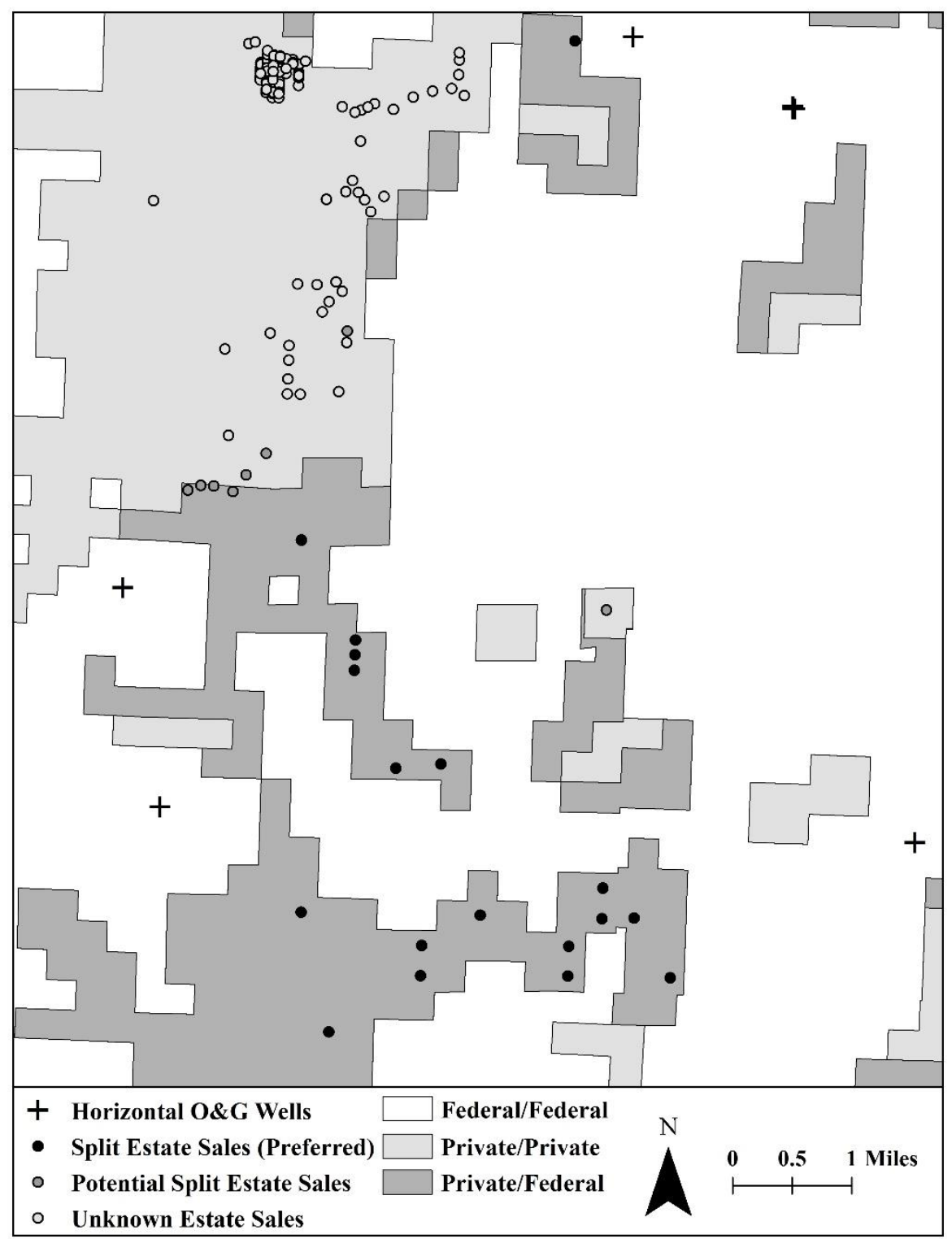

Notes: Horizontal oil and gas well data is from Drillinginfo. Split estate sales represent transactions of properties with boundaries that are completely within the federal mineral ownership boundaries from the Bureau of Land Management. Potential split estate sales are those transactions of properties that overlay, but are not within, the federal mineral ownership boundaries. Unknown estate sales are transactions of properties that do not overlay, even minimally, areas with federal mineral ownership. Private/Private and Private/Federal indicates the intersections between privately-owned land with privately-owned minerals and federally-owned minerals, respectively. Federal/Federal are government lands in which both mineral and surface rights are owned federally. 
Figure 3: Distance bin parameter estimates and histogram of well distance
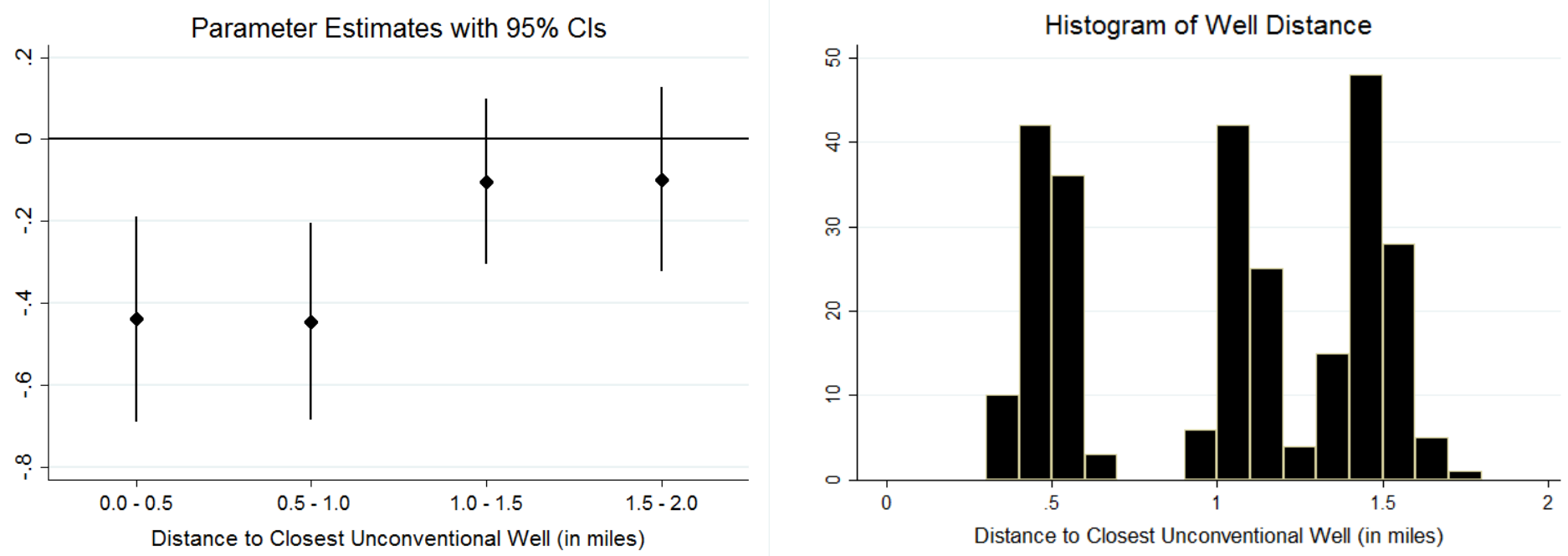

Notes: In the left graph, we highlight parameter estimates for distance bins in line with Equation 4 . We define our treatment variable as a bin variable (see Equation 5). Each estimate reflects the impact of the closest well from the property drilled within the distance bin range, relative to the omitted category of having the closest well drilled beyond two miles. In the right graph, we highlight the distribution of distance to closest unconventional well. We only include those wells that were drilled before the sale of the home. 
Figure 4: Propensity score distributions for one mile treatment, pre versus post matching (Nearest Neighbor $3-1$ )
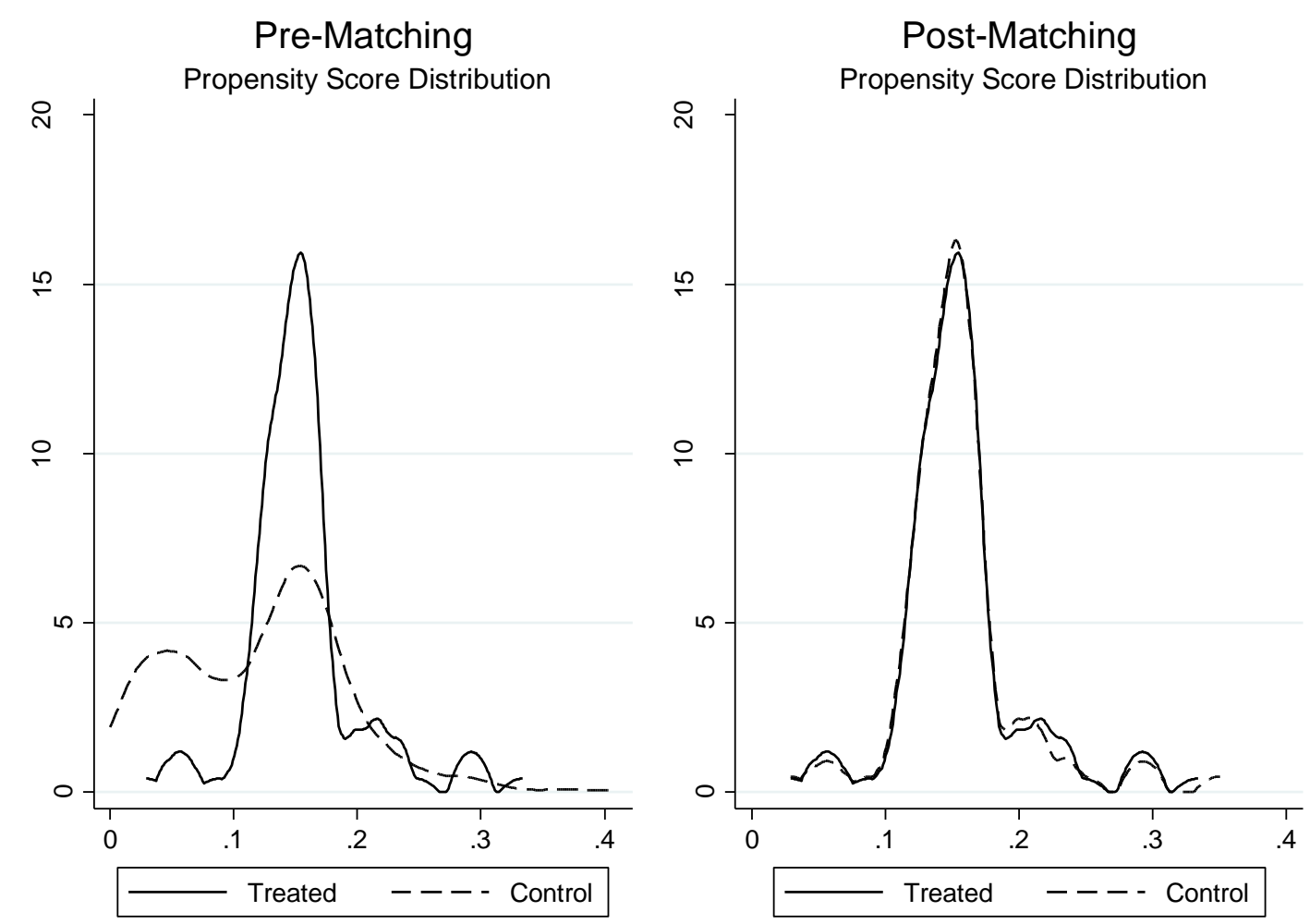

Notes: These graphs highlight the difference in propensity score distribution, pre versus post-matching. Variables included in the propensity score estimation include the \# of bedrooms and bathrooms, parcel acreage, property finished living area, property age, distance to the closest municipality, the percentage of the property in an agricultural use, and the number of vertical oil and gas wells drilled within a mile from 1980 to 1999. 